\title{
Research on the Inheritance and Innovation of Folk of "Doumen Water Wedding" in Zhuhai
}

\author{
Zhexin $\mathrm{Liu}^{1, *}$ \\ ${ }^{1}$ Zhuhai College of Jilin University, Zhuhai, Guangdong, China \\ *Corresponding author. Email: 38383822@qq.com
}

\begin{abstract}
This paper conducts a comprehensive research on the inheritance and innovation methods of "Doumen Water Wedding", and analyzes its existing problems and difficulties. It compares and fully draws on the successful experience of intangible cultural heritage inheritance in various regions through inquiries on literature, questionnaire surveys, visits to cultural centers, exhibition halls, field trip experience, and interviews with intangible cultural heritage inheritors and related persons in charge. It also puts forward suggestions and countermeasures for the inheritance and development of the "Doumen Water Wedding" in Zhuhai. "Water wedding" needs to start from the actual situation to simplify or change the etiquette process, advertise through modern new media, reasonably use the government, enterprises, schools and other social resources to establish intangible cultural heritage training institutions and train inheritors, create a "culture + tourism" characteristic tourism belt, create a special brand for wedding celebration to promote it to the commercial market, create cultural and ecological protection areas, etc. to coordinate the development of inheritance and innovation, and find new vitality in the modern society to make it more substantial and perfect, and make the folk culture continue in the end.
\end{abstract}

\section{Keywords: intangible cultural heritage, water wedding, inheritance and innovation}

\section{INTRODUCTION}

Zhuhai's cultural heritage is very profound, and its traditional culture has a long history, especially the "Doumen Water Wedding". "Doumen Water Wedding" is the first national intangible cultural heritage list approved by Zhuhai City. Water wedding is a traditional folk custom that has been popular in Doumen Water Village for hundreds of years. After hundreds of years of spreading and the integration and precipitation of several generations, the unique wedding folk customs of Doumen Water Village have been formed. Its main characteristic is that the wedding process and forms are complex and diverse, and it pays attention to etiquette and has relatively fixed procedures for wedding etiquette items. The etiquette mainly includes "坐高 堂" (sitting in the main hall), "上头" (in the old days, women wore their braids when they were not married, and then tied up their hair into a bun when they were about to get married", "叹家姐" (before "crying marriage", the mother and daughter, sisters and bridesmaids sing in antiphonal style), "花船迎亲 " (use a flower boat to fetch the bride), and "回门" (the return of a bride to her mother's home on the third day of the wedding), etc. It is inseparable from the water environment of residence and life, and has obvious characteristics of "water". Such as "花 船迎亲" (use a flower boat to fetch the bride), and worship to "Ship Tagaung", "Sea Dragon King", etc. In addition, for example, it is closely integrated with tidal land folk songs, and antiphonal songs are interspersed in the wedding ceremony.

\section{DEVELOPMENT HISTORY}

According to historical records, in the Ming Dynasty, there were the Dan people living in Dashatian area in Doumen. In "Xiangshan County Local Records", it records, "People living in the water are called the Dan (蛋) people. Now it has been ordered to be retrenched and removed by the officials of Sanzao in this county... The Dan people are stubborn and intrepid, so in the beginning of Ming Dynasty, they were used as soldiers to implement the strategy of conciliation rather than the strategy of inducing. Therefore, the Dan people's custom is after all different from the locals. In the seventh year of the reign of Yongzheng in Qing Dynasty, the Dan people who were capable of building houses were allowed to live in the villages near the water and till the land to commit to the 
fundamentals, so as to show the emperor's treating people equally without discrimination... The Dan people use ships as their houses, taking fishing or braiding grass peng as their business, and living by the water, which is called water railing." (水居则为 螢民, 今本邑三灶官久已奉裁。……至蛋民顽悍, 明初籍以 为兵, 实羁縻之术, 非诱之向化也, 故风俗习惯, 究与土著 不同。清朝雍正七年, 诏令蛋民有能盖屋栖身者, 许其在近 水村庄居住, 力田务本, 以示一视同仁。……㞼人, 以舟为 宅, 业捕鱼或编篷, 濒水而居, 谓之水栏。) (See "Ci Yan": Dan means the boat dwellers in the ancient south. It is also known as "蛋", and today, it is regarded as "疍".)

The custom of Doumen Water Wedding originated from the etiquette of the Dan family's marriage. It was formed in the early Qing Dynasty and matured during the reign of Emperor Guangxu in Tongzhi of the Qing Dynasty. It combines elements of Cantonese culture and Hakka culture. In several links such as preparing the wedding banquet, picking up the bride, worshiping the parents, welcoming friends with singing, etc., it uses boats as a means of transportation, and uses saltwater songs to run through the whole process of wedding activities.

$\mathrm{Qu}$ Dajun, a scholar from the early Qing Dynasty, wrote in "Guangdong Xinyu": "The Dan people regard boats as their home, which is therefore called 'Danjia' (蛋家). If a male is not married, he will place a pot of grass at the stern of the ship; if a female is not married, she will place a pot of flowers at the stern of the ship, which will attract matchmakers to make a match. When they get married, they meet each other with singing. And if the male wins in the battle of singing, he will have the opportunity to marry the female and get ahead of the former ship." (诸蛋以艇为家, 是曰 “蛋 家, 。其有男未聘, 则置盆草于梢; 女未受聘, 则置盆花于 梢，以致媒妁。婚时以蛮歌相迎，男歌胜则夺女过舟。)

After the Jiaqing Daoguang period of the Qing Dynasty, the quicksand of the Xijiang River system had silted up around Huangyang Mountain into a series of sandy beaches, mainly including Shanghengsha, Minyusha, Weijiasha, Denglongsha, Qinghe Bay, and Dahaihuan. At that time, wealthy people living in Doumen, Baijiao, Ganwu and other villages applied to the local government for land tax declarations, hired tenant households and Dan people for reclamation, and developed fertile fields in these sandy beaches and bays. These tenant households and Dan people became residents of the Dashatian area. They lived by the banks of the river and depended on farming and fishing for a living. The unique water culture is also gradually formed along with the lives of the people in the water village. Doumen Water Wedding custom is one of them. Every wedding is a big gathering of people in the aspects of benevolence etiquette, clothing, furnishings, folk songs, etc. Its cultural charm has been influenced and spread to other Dashatian areas in the Pearl River Delta such as Zhongshan, Jiangmen, and Foshan. In the early years of the Republic of China, Doumen Water Wedding had become a household custom in Dashatian Water Village. The creation and singing activities of Shatian folk songs are also colorful, even popular throughout the Pearl River Delta. So far, Doumen Water Wedding custom has entered a period of prosperity. As a kind of local culture that the masses love to see and hear, it has left a splendid page in the development history of Lingnan culture.

\section{DILEMMAS}

\section{A. Changes in the social environment}

As a traditional life etiquette, the custom of Doumen Water Wedding is still respected and adopted by the residents of the water village, especially the older generation. However, due to the influence of modern civilized marriage etiquette, this traditional form is under attack. Many young people think that traditional wedding rituals are too complicated, and their wedding ceremonies when they get married have gradually been simplified. Some of its etiquette procedures and related utensils have also been replaced by new things. For example, the popularity of modern songs has made the crying and sighing or salt water singing accompaniment ceremony of the original wedding "sigh" gradually decline, the bride and groom's clothing colors are changed, and the "flower boat" used to greet the bride are gradually replaced by cars. In addition, with the acceleration of urbanization, rivers are narrowing and water quality is getting worse and worse. The deterioration of the surrounding environment has an immeasurable impact on folk culture.

\section{B. Lack of inheritors}

Those who really know how to arrange this etiquette are only those elderly people over the age of 50 or 60 , and there are very few young and middle-aged people who know how to arrange water wedding rituals. It can be seen that there will be few successors to the traditional water wedding etiquette and customs in Doumen. The salt water songs and Gaotang songs that appeared at the wedding were originally the highlight of traditional water weddings, but nowadays, almost no young people can sing them. As the main tunes of Shatian folk songs, salt water songs and Gaotang songs are valuable historical and cultural heritages in Zhuhai area. But unfortunately, with the emergence of new entertainment methods such as movies, TV, radios, and karaoke bars, entertainment methods of folk songs celebration methods and singing in antiphonal style have no living space, and the number of inheritors continues to decrease. Shatian 
folk songs are facing the dilemma of lack of inheritors.

\section{INHERITANCE AND DEVELOPMENT PATH OF "DOUMEN WATER WEDDING"}

The essence of intangible cultural heritage inheritance lies in skills and thoughts, and it is the inheritance of production technology, the inheritance of traditional cultural spirit, and the embodiment of traditional Chinese craftsman spirit. In the process of inheriting intangible cultural heritage, it is necessary to accurately recognize the nature of intangible cultural heritage, and reasonably retain and abandon it. The vitality of intangible cultural heritage lies in 'expression'. In the inheritance of intangible cultural heritage, it is necessary to "remain essentially the same despite all apparent changes", presenting a face that is both traditional and fashionable, ancient and fresh (Wu Longgui, 2019). In the current era of new media, traditional culture should be combined with the current environment, flexibly use modern methods and language to express, and find a model of inheritance and development that matches itself.

\section{A. School-enterprise alliance to establish intangible cultural heritage training institutions and train inheritors}

As the living carrier of intangible cultural heritage, the inheritor is particularly important in inheritance and innovation. In view of the current situation of "water weddings" with no inheritors, it is necessary to clarify the core of people-oriented and establish relevant mechanisms and institutions to protect intangible cultural heritage inheritors. For example, it can cooperate with schools and enterprises to carry out a series of related traditional mechanisms of "water wedding", spread the cultural connotation of "water wedding" by explaining and imparting relevant knowledge to school students and employees, enable young people to know more about the meaning behind the water wedding ceremony, let life have more sense of ceremony, let couples experience the happiness of marriage, and cultivate talents who are interested in the traditional customs of "water wedding" and intend to learn more. This can help increase the spread of this traditional custom, enhance the sense of identity of the masses, and cultivate contemporary students' awareness of the protection of intangible cultural heritage, and enhance the atmosphere of traditional culture on campus.

In recent years, the Intangible Cultural Heritage Protection Center of Doumen District has vigorously promoted the work of intangible cultural heritage into campus, and has gradually popularized intangible cultural heritage inheritance and protection in schools and kindergartens throughout the district. Since the Lantern Central Primary School of Baijiao Town was designated as the characteristic education base of Shatian folk songs in 2016, it has continuously innovated the inheritance and protection form of the list and achieved good results.

\section{B. Keeping pace with the times and improving part of the wedding process}

There are 13 fixed procedures in Doumen Water Wedding, and the etiquette includes "坐高堂", "上头", "叹家姐"，"花船迎亲"，"拜堂"（performing the formal wedding ceremony), and "回门", etc., and there are relatively fixed procedures and the use of conventional use items. Because people have not adopted the water wedding for too long, some traditional customs have also been forgotten, and even some elderly people are unable to decide which is right in terms of the specific use of some props. According to contemporary people's aesthetics and current situation, part of the wedding process needs to be improved and simplified. Old songs have to be sung with new forms to attract listeners. Traditional things must be endowed with practical value in contemporary times to be preserved. Only by improving or simplifying the procedures of water wedding and advancing with the times can make the water wedding be liked and chosen by more young people.

For example, as the times change, many ceremonies have been simplified. In the past, the more important part of "water wedding" was not the singing in antiphonal style of welcoming the bride, but the "sighing" of the sisters-in-law. In recent years, when restoring water wedding in other water areas, they often focus on the part of fetching the bride, simplifying the "sighing" link. Another example is that, previously, the groom didn't have to go to fetch the bride, and the bride took the boat to her husband's house by herself. However, this practice is obviously not in line with the requirements of the times, so the groom needs to fetch the bride nowadays.

\section{The government should intervene to create a "culture + tourism" characteristic tourism belt}

Culture and tourism are current hotspots, but the connection of the two is not simply to list them together, but to explore the traditional cultural genes on the tourism route and find out the commonality and uniqueness of the regional culture, so as to form tourism cohesion, thus forming a healthy combination of culture and tourism. Doumen has abundant tourism resources, and government departments can reasonably use and develop local tourism resources. By providing venues and funds for water weddings and other intangible cultural heritage, they can establish related intangible cultural heritage museums and 
exhibition halls and experience activities, fully explore the highlights of "water wedding" in line with the current era, and connect surrounding scenic spots with intangible cultural heritage to create a distinctive culture and tourism belt.

During the investigation, it is learned that Zhuhai City Government and Doumen District Cultural Center and other relevant departments are constantly exploring the cultural connotation of this folk custom, focusing on the normal training, inheritance of the original ecology, dynamic publicity, and solid display articles, insisting on holding the series of activities of "Cultural and Natural Heritage Day" in Zhuhai, "Doomen Water Group Wedding", folk culture festivals, and intangible cultural heritage publicity and popularization, and connecting with surrounding scenic spots to realize the characteristic tourism belt of "culture + tourism" to provide effective power and support for the inheritance of "water wedding" and the development of the local economy, and actively create a characteristic tourism belt of "combination of culture and tourism and rural revitalization".

\section{Using Internet new media platforms to expand communication channels}

In the current era of Internet and new media, "water wedding" should make full use of favorable conditions such as multimedia and multi-channels and rapid information to promote awareness, attract more attention, and form new communication hotspots. At present, the "Doumen Water Group Wedding" annually recruits newcomers from around the world to participate, which has played a very important role in the spread and popularity of the "water wedding" custom. But this is far from enough. Through the investigation of the author's project team, it is found that the broad mass doesn't particularly know the water wedding. The promotion and publicity of "water wedding" can be achieved by choosing the communication method that best fits the current mainstream environment. For example, it can make use of short video platforms such as Tik Tok and Kuaishou to make publicity by shooting and publishing short videos about "water wedding"; it can publish articles about "water wedding" on Internet platforms such as Microblog, Toutiao, and WeChat public platforms, so that more groups can learn about the history and culture of "water wedding" and increase social attention.

\section{E. Establishing a wedding culture brand and promoting the commercial development}

Culture is the soul of a brand, and a brand is the carrier of culture. In the process of consumption, consumers will not only value the functionality of the product, but also value the spiritual satisfaction and agreement. It can use "water wedding" to cooperate with cultural creative company to plan and develop "water wedding" brand, create a complete wedding cultural and creative industrial chain that integrates wedding dresses, wedding etiquette, wedding banquet services, wedding photography, live-action props, makeup jewelry, etc., arrange a boutique wedding culture event that integrates cultural exhibitions, art performances, and leisure tourism, build the brand of "water wedding", and seize the selling point of "wedding celebration" to promote the "water wedding" to the market in the inheritance and commercialization. And its market prospects will be immeasurable.

\section{F. Creating a cultural and ecological protection zone}

Doumen in Zhuhai is a primitive place where the Danjia culture has accumulated richly. It has the characteristics of Danjia cultural clothing, food, weddings and funerals, hospitality etiquette, festivals and entertainment, ethnic crafts, etc. In Doumen, a unique folk culture landscape of Danjia culture has been formed. So far, "Doumen Water Wedding" and "Catching Mud Fish" have been included in the national intangible cultural heritage protection list. Among them, "Doumen Water Wedding" is the most representative cultural symbol in Danjia culture, presenting the local customs of Doumen Water Village, which not only integrates Cantonese culture, but also permeates the elements of Hakka culture.

The creation of the Danjia Cultural Ecological Preservation Area is conducive to building a local cultural tourism brand in the Guangdong-Hong Kong-Macao Greater Bay Area. As an important city connecting Shenzhen, Hong Kong and Macao, Zhuhai has a unique geographical advantage. It can form a unique Danjia Cultural Ecological Preservation Area by virtue of the rich customs of the Danjia culture such as Doumen "Water Wedding", strong local colors, and distinctive water village characteristics. Utilizing its extremely high tourist value and cultural value is not only conducive to protecting traditional intangible cultural heritage such as "water wedding", but also conducive to promoting the cultural integration and development of the Guangdong-Hong Kong-Macao Greater Bay Area and boosting the revitalization of the rural economy.

\section{CONCLUSION}

Intangible cultural heritage is the precious wealth left by the predecessors, the continuation of the national spirit, and the cornerstone of social development. As a national intangible cultural heritage, "water wedding" reflects the marriage customs of the Dan people, and has a strong 
historical profundity and profound cultural connotation. With the development of the times, it's needed to start from the actual situation, pass on the "water wedding" through modern technology and forms, and reasonably use the government, enterprises, schools and other social resources to coordinate the development of inheritance and innovation. In the end, it will find new vitality in a modern society and carry forward their own cultural connotations in a diverse cultural ecology.

\section{Acknowledgment}

This article is one of the phased research results supported by the Zhuhai City's Philosophical and Social Science Planning Project "Research on the Inheritance and Innovation of Folk Culture of 'Doumen Water Wedding'" (project number: 2019GJ254).

\section{References}

[1] Guo Daorong. The Inheritance and Development of the Folk Culture of "Doumen Water Wedding", Zhuhai Daily, February 10, 2018. (in Chinese)

[2] Song Lixing, Li Xiaoxia. On the Evolution of Guangdong Dan people's Folk Marriage Customs - Taking Hailing Island in Yangjiang City as an Example [J], Journal of Guangdong Polytechnic Normal University, 2015, 04. (in Chinese)

[3] Yan Guangwen. From "Oudeng" to Dan people - A New Explanation of the Origin of Dan People [J], Guangdong Social Sciences, 2015, 02. (in Chinese)

[4] Fan Youmeng, Xie Yanjun. Memory, Display and Gaze: Collaborative Research on Rural Cultural Heritage Protection and Tourism Development [J], Tourism Science, 2015, 01. (in Chinese)

[5] Yao Lei. A Review of Studies on the Inheritance of National Culture in China [J], Study of Ethnics in Guangxi, 2014, 05. (in Chinese)

[6] Tao Wei, Chen Huiling, Cai Shuiqing. The Influence of the Reconstruction of Traditional Folk Festivals in Lingnan on the Local Attachment of Residents - A Case Study of Guangzhou Zhu Village's Qiqiao Festival [J], Acta Geographica Sinica, 2014, 04. (in Chinese)

[7] Chen Jing. The Paradox of the Intangible Heritage "Inheritor" System in the Protection of Ethnic Literature and Art [J], Guizhou Ethnic Studies, 2014, 01. (in Chinese)

[8] Song Lixing. Investigation on the History and Current Situation of the Traditional Culture and Customs of the Dan People on Hailing Island, Yangjiang, Guangdong [D], Guangdong Polytechnic Normal University, 2016. (in Chinese)

[9] Dong Ligong. A Preliminary Study on the Marriage Customs of Dan People in Guangdong [J], Journal of China University of Geosciences (Social Science Edition), 2013, S1. (in Chinese)

[10] Li Lejing. Research on the Conflict of Interests and Coordination Mechanism in the Tourism Development of Ethnic Villages [J], Ecological Economy, 2013,11. (in Chinese)

[11] Xu Ruiying. An Empirical Study on the Conflict of Interests of Stakeholders in Rural Tourism Development
Based on Game Theory [D], Zhejiang University of Finance and Economics, 2018. (in Chinese) 